\title{
Duodenal Infection
}

National Cancer Institute

\section{Source}

National Cancer Institute. Duodenal Infection. NCI Thesaurus. Code C78258.

An infectious process affecting the duodenum. 